\title{
Application of the Hegemony Theory from Gramsci: A Case Study of the Success of Recording Death Data in Bumiayu Subdistrict, Brebes District, Central Java
}

\author{
Ratih Ariningrum $^{1 *}$, Meutia Farida Hatta Swasono ${ }^{2}$, Irwan Martua Hidayana ${ }^{3}$ \\ ${ }^{1}$ Researcher at The Center of Research and Development in Humanities and Health Management, National Institute of \\ Health Research and Development, Ministry of Health, Indonesia. \\ ${ }^{2}$ Professor at Study Program of Anthropology, Faculty of Social and Political Sciences, University of Indonesia, \\ Indonesia \\ ${ }^{3}$ Lecturer at Study Program of Anthropology, Faculty of Social and Political Sciences, University of Indonesia, \\ Indonesia \\ *Corresponding author. Email: rariningrum@ rocketmail.com
}

\begin{abstract}
There are many areas which coverage of death data recording is still below the predicted mortality rate in the region. Death data recording in the Bumiayu region exceeds the predicted mortality rate in the region. In the pre-study there were indications of a link between the social system and the bureaucracy in the work of data collection. This study aims to analyze the social system that develops in the Bumiayu community if there is a death of a family member, explaining the integration of the social system and the bureaucratic system in the work of collecting death data, and analyzing hegemony relations that develop in the recording of death data. A qualitative approach with ethnographic strategy was used in this study. The hegemony relationship that developed started from the idea of recording death data into an ideology, an active commitment, until an equilibrium was formed between the governing and governed parties making it easy for the activities to run. Implementation of death data recording needs to understand and apply the local social system through approach of Gramsci's theory of hegemony.
\end{abstract}

Keywords: Sample Registration System, social system, hegemony, organic intellectual

\section{INTRODUCTION}

Constitution number $36 / 2009$ on health states that the Health Information System (SIK) is implemented through cooperation between sectors [1]. Constitution number 23 of 2006 regarding population set by the Director General of Adminduk (Directorate General of Population Administration, Ministry of Home Affairs, 2006) set that every death must be reported within 30 days [2]. Therefore, in 2010 a Joint Regulation of the Minister of Home Affairs and the Minister of Health Number 15 of 2010 (Number 162/Menkes/PB///2010) was established concerning Reporting of Death and Causes of Death [3]. At present, death statistics and medical information about causes of death from health facilities (hospitals) are still inadequate, due to the limited coverage of hospital users. Then, Indonesia carried out an activity called the Sample Registration System (SRS) with funding from the Global Fund.

\begin{abstract}
This research was conducted in Bumiayu Subdistrict which is one of SRS sample area in Central Java. Recording of data on mortality in Bumiayu exceeds the predicted mortality rate in the region, so it can be used as a case study to see the cause of the success of the activity. Important factors supporting the high recording of data on mortality in Bumiayu Subdistrict have been observed at the time of pre-study. There is an indication of the linkage between the social system and the bureaucracy at work of collecting data on mortality that support smoothness and achievement of coverage. In addition, there is a hegemony relationship in the activity of recording data on mortality in Bumiayu community. Therefore, I argue that based on data on the achievement of coverage and observation during pre-study, this research needs to be carried out.
\end{abstract}

This research aims to analyze the social system that develops in Bumiayu society if there is death of family member and the role of the system in supporting the smoothness of recording of data on mortality in Bumiayu Subdistrict, explain the integrity of social system and bureaucracy system contained in the framework of collecting data on mortality, and analyze the growing hegemonic relationships 
in recording of data on mortality. Research activities about recording data on mortality by looking at the integration of the growing social system and bureaucracy in the work of data collection, not only is the study in the field of health, but also in the field of social science, especially anthropology that uses socio-cultural approach. Research on the topic can be fairly new. A country, like Indonesia, with its multitude of cultures causes a diverse range of social systems. Furthermore, the social system of a society that supports the implementation of a policy is not enough just to be pronounced. How many people say how important it is to see the culture of a local community, but not a few who view culture as merely a phrase to show things that lead to the past, the occult, or merely a show that features something traditional, such as dance or performances folklore. Culture is a way of life that is developed and shared by a group of people and passed down from generation to generation. Culture is made up of many elements, including religious systems, customs, language, tools, clothing, buildings, and artwork. Culture is not biologically derived or inherited through the genetic elements. Culture that exists in humans is owned by way of learning. Humans learn to make everything that can change and give new forms and meanings to all of God's creation according to the needs of every human being. That change is called culture.

In the recording of data on mortality, on the one hand, the disclosure of what and how social systems exist in the community is very necessary, because it relates to all the habits underlying the community to do something. The social system referred to here is the social system that deals with take care of the corpses. Local lebai usually takes care of the corpse. Every lebai always reminded the rules of Islam that a deceased person should be buried. The people of Bumiayu are very obedient to the rules. On the other hand, the bureaucracy referred to here is the bureaucracy associated with the work of collecting data on mortality. The bureaucracy must be considered for the passage of a rule. How does the bureaucracy found in the collecting of data on mortality support the recording of data of mortality? How integrate with social system so that can support the smoothness of activity of recording of data on mortality? All that requires a deep study, which is not only limited to social culture of the people superficially.

Based on the literature review and pre-studies that have been conducted, the research on the relationship between the social system and the bureaucracy contained in the framework of the collecting of data on mortality affecting the smoothness and achievement of coverage was first implemented. In some countries that have implemented SRS activities, there has never been any research on the local social system in relation to the activity of recording of data on mortality. Jennaway et al, (2009) [4] has conducted research activities on culture in relation to the recording of data on mortality in Indonesia. The research activities are carried out not on SRS activities, but on IMRSSP activities. Research Jennaway et al, has differences in terms of methods and substance with research that has been conducted by researcher. In Jennaway's research, the methods used for data collection are field observation, focus Group Discussions (FGDs), and semi-structured Interviews (SSis). The study has several objectives focusing on religious and cultural habits related to death, study on procedures for obtaining death certificates and community views on death reporting, and studies on verbal autopsy processes and community responses on verbal autopsies.

\section{METHOD}

The study used a qualitative approach with an ethnographic strategy. Locke, Spirduso, and Silverman (2007) argue that qualitative research is an interpretive study, in which researchers engage in sustained and continuous experience with participants. It is this involvement that will bring up a series of strategic, ethical, and personal issues in the process of qualitative research (Cresswell, 2010: 264) [5].

The data collecting is done by observation of social system and bureaucratic system of recording of data on mortality in Bumiayu Subdistrict, observation of growing relation on recording of data on mortality in Bumiayu Subdistrict, participant observatory to know the social system and bureaucratic system that has been implemented in recording of data on mortality in Bumiayu Subdistrict, open interview, and searching of secondary data.

Research subjects are officers who are members of the SRS (midwives, nurses, doctors at Puskesmas), Kaur Kesra in Kalierang Village, Head of Kalierang Village, Kaur Kesrain Pruwatan Village, Head of Pruwatan Village, Secretary of Bumiayu Subdistrict, Statistics Section of Bumiayu Subdistrict, SRS Respondents, Staffs of Bumiayu Community Health Center, Staffs of Kaliwadas Community Health Center, Health Cadres in Kalierang Village, and Health Cadres in Pruwatan Village.

Conceptual framework can be explained: the process of creating hegemony requires what is called a 'historical bloc', or reciprocal relationship between ethical, political, and ideological activity with economic territory. The historical block is an alliance of various social forces that are united politically within a set of hegemonic ideas. The hegemony itself is created through the practice of subjugation and approval. While subjugating and winning the consent of another group, a group must be able to create a 'historical bloc' in order to fight for its ideas into a universal worldview. Therefore, 'idea' plays an important role. In order for a group to subdue and win the approval of another group, it must 'import' the idea. Therefore, for Gramsci, an idea will only find its transformative momentum if it becomes an ideology. The ideology must have a material base, driven by an 'intellectual,' and then become a universal view.

According to Gramsci, everyone is intellectual, but not everyone has an intellectual function (in society). The center of role intellectual which then brings that power into a hegemonic power. Gramsci defines hegemony as a cultural leadership run by the ruling party. Hegemony is different from coercive executed by the owners of both executive and 
legislative power. Moreover, what distinguishes Gramsci from early Marxian thinking is that if the early Marxians focused on economic determinism and the coercive aspect of state domination. Gramsci focused on the hegemony of cultural leadership.

Gramsci argues that hegemony does not automatically come from those who have economic dominance of the ruling class, but it is something to be built and strived for. The ruling group builds its hegemony by maintaining moral and cultural leadership.

There are several considerations underlying the use of Gramsci's hegemonic theory. The first consideration is based on the existence of several teams that support the implementation of activities. The first task of SRS team members is to make the parties to understand about the activities of recording data on mortality. Then the next task is to make the stakeholders understand the purpose of the activity and know the ways to achieve the success of the activity. In other words, SRS team members should make sure that the relevant parties can accept the thoughts of SRS team members without compulsion, so that the activities can be successfully. The hegemony of SRS team members in this case is necessary in disseminating information, embracing, and maintaining the continuity of activities. The second consideration is the need for PJO and health workers in the SRS team to observe the local customs (formations/social system) that exist in the community towards the hegemonic process. Implementation of a policy in the health sector should pay attention to the social system that develops in the local community.

It would be important to analyze all the consequences of one of the propositions in the introduction in A Contribution to the Critique of Political Economy by Marx which mentions (Gramsci, 1987: 788) [6]:

"A social order is not destructive until all its productive forces that have been space, developed and new and higher production relations have taken their place, until the material conditions of these new relationships have grown in the womb of ancient society."

Gramsci reaffirmed the passage in his own words (Patria and Arief, 2003: 80-81) [7]:

"A social formation does not disappear before all productive forces have been developed, and new higher production relations will not replace it before conditions for its existence have been developed in the womb of the old society ..."

Based on the social philosophy of Gramsci, it can be drawn an understanding that the policy to be developed in an area must first prepare the policy, so that acceptable to the local community.

For Gramsci, the hegemonic process occurs when the way of life, the way of thinking and the thinking of inferior community have imitated and accepted the way of thinking and lifestyle of the elite who dominated and exploited them (Simon, 2004: xiii-xiv, xviii-xix) [8]. The process of acceptance of the way of thinking and lifestyle of the group must be accompanied by the development of conditions to support its existence.

Based on the above explanation, the hegemony is not the relationship of domination by using power, but the relationship of agreement by using political and ideological leadership. Hegemony is a consensus organization (Simon, 2004: 19-20). According to Gramsci, there are certain developmental stages that social groups must pass before they can become hegemonic (Brown, 2009) [9]. Gramsci then states that there are three levels of political development that a social group must go through in order to develop a movement to initiate change. The first stage is the need for support of others to obtain their own security. The second stage is the members of the group begin to realize that there are others who share their interests. It is in this stage that a sense of solidarity develops. The third stage that members of social groups begin to realize the importance and need to go beyond what they can do. They need to have these interests support by other groups.

Team members' hegemony is maintained with the collectivity (active participation) and discipline of all parties involved in the activities. Collectivity and discipline even though it seems that things are common in relationships to run an activity, but that aspects are very meaningful in the success of recording data on mortality.

Gramsci also explained that the active participation of team members is very important eventhough this could causing signs of division and disagreement. Gramsci:

"Collective consciousness, in other words living organisms, is not formed except after the uniformity of diversity through friction within party members. It can not be said that 'silence' is not a diversity. A practicing orchestra, every musical instrument being played gives the impression of a frightening frenzy. But this exercise is important for the orchestra to remain "singular" (Simon, 2004: 156) [8].

This SRS activity is a team activity. Each team member has a task. These tasks are interrelated. The success of the activity will be realized if all members have awareness to perform their respective roles. If there is one part that overrides it, then it is impossible that the target attainment of coverage will be realized.

Gramsci also emphasized the need for self-discipline. Moral arguments about discipline are used as a means of selfimprovement and collective freedom. Gramsci:

"Collectivity must be understood as the product of the development of will and mutual thinking through the concrete individual effort and not through the process of fate outside the individual; it takes an inner discipline and not just outward and mechanical discipline. If there are polemics and disputes, we should not be afraid to face it and resolve it because it can't be avoided in this developmental process, and avoiding it simply means delaying it which will then be dangerous and even catastrophic, and so on." (Simon, 2004: 157)[8]. 
Researcher examine the social system associated with mortality in the community Bumiayu and bureaucracy at the work of collecting data on mortality using the thoughts of Antonio Gramsci. The bureaucracy referred to in this study is the bureaucracy found in the work of collecting of data on mortality. The collection of data through several stages of activity that includes: the collection of information on the incidence of death, synchronization of data on mortality, interviews, resume and diagnosis determination, and delivery of reports to relevant agencies. All these stages involve the work of the bureaucratic apparatus. Lebai and the bureaucrats involved in these activities are intellectuals who can create historical bloc. They have been able to fight for an idea so that the idea can be accepted by society. Lebai is someone who has religion knowledge in the field of religion, in this case is Islam. Based on the knowledge, lebai urge that every citizen who died as soon as possible buried. For this purpose, residents quickly report to lebai for the take care of the corpse. The bureaucrats have also been able to play an intellectual role and create a historical bloc. They have been able to embrace other parties to support this activity.

\section{RESULTS AND DISCUSSION}

\section{Results}

\section{Social System and Bureaucracy on the Work of Reporting Data on mortality}

The first thing that underlies Bumiayu's social system is the strong and deep-rooted influence of Islam. This can be seen from the first school in Bumiayu is Ta'allumul Huda which was founded in 1915 and then followed by the establishment of Al'Irsyad Al Islamiyah Institute in 1919 which is the fourth branch in Indonesia, followed by the establishment of Muhammadiyah in 1922. Researchers observed that a strong Islamic influence cause consensus on Bumiayu society regarding the taking care of the corpse. In accordance with the teachings of Islam, someone who died must be buried soon. In addition, in the teachings of Islam, the leader of Islamic teachings is one of the parties that must be obeyed. Mr. Abdul Karim Nagib, one of Bumiayu community leaders, said:

"One must obey Allah, the Prophet, and the leader. Because of a strong religious foundation, it is easy (to invite Bumiayu community) if there is any activity, unless the activity violates the shari'a."

Kaur kesra who also served as lebai in Pruwatan Village (Mr. Sarjono) explained that the strength of the world is determined by four things, namely:

"The existence of the scholars, the existence of the government, generous rich people, and the prayers of the poor."

The population of Bumiayu who are predominantly Muslim strongly uphold the guidelines. Bumiayu society in terms of reporting the death is to report to the local lebai if there is one of family member died. Lebai is regarded as the "leader" for the community in his village. Marriage, divorce, and death events are always reported to the village officer. The village officer in this case is the head of the people's welfare affairs (kaur kesra). In each village only one person is special as kaur kesra. But in one village there can be some lebai. In addition to taking care of the corpse, lebai duty as officer who help record marriage. In the village of Pruwatan there are some people who served as lebai. Those people are Mr. Sarjono, Mr. Abdul Rosul, and Mr. Abdul Hamid. But for the Village Pruwatan, lebai who also served as kaurkesra is Mr. Sarjono. While in the village of Kalierang, the officer is Mr. Agus. Pak Agus said: "In Brebes, lebai, kaur kesra, and P3N into one, one package". Mr. Agus's task as lebai in Kalierang Village was assisted by Mr. Riyono .

Mr. Rosul told of the history of the community members who were appointed as lebai. According to him, lebai or Javanese used to call him a modin priest, is a man of good religious knowledge:

"People who are cleverly appointed to be priests, including to take care of the corpse".

Geertz in his book (1983) [10] describes:

"... all the cemetery is no doubt still held by modin, the official religious official in the village. Only a few people occasionally invite him to recite prayers at the ceremonies of birth and circumcision (he is almost always a strong santri), and in every case of marriage he must bring the groom to the naib office to carry out the Islamic part of the marriage ceremony; but in death he actually acts alone as the general leader of all matters. "

Although there are families who can take care of the corpse of their family members, the reporting is still done to the local lebai, because lebai continue to provide guidance to the family members, until the family members who are dead are buried. On the other hand, the bureaucracy contained in the framework of data on mortality collection needs to be considered to support the smooth recording of data on mortality.

\section{Intellectual Role: Lebai and SRS Team Members}

Intellectual hegemony highlights two principles: 1 . The general conception of life, a philosophy (Gioberti) that offers the intellectual "dignity" to its followers to draw the principle of differentiation from the old ideology dominated by coercion and elements of the struggle against it; 2 . Learning programs, educational principles and early pedagogy that interested with intellectual fractions in the most homogeneous and most numerous (teachers, from school teachers to university professors), and giving activity technically (Gramsci, 1983: 285) [6].

The role of lebai is very obvious in relation to the dissemination of religious knowledge, especially regarding the taking care of the corpse. Lebai as one of the religious leaders in Bumiayu has managed to build a habit that refers to the rules of Islam that a deceased person should be buried soon. The belief laid out by the lebai make lebai can be incorporated as organic intellectual that highly influential in the social system about the taking care of the corpse in the Bumiayu society. Lebai has a good foundation of religious science, in this case is the science of the taking care of the corpse. Lebai's religious science makes lebai has a hegemonic social power.

In this study SRS team members are considered as intellectuals who also play a role in organizing activities. 
They can inform and invite other parties to actively support the activities. In addition, their role to connect inter-agency cooperation is also critical to the success of this activity. The first, role of intellectual was shown during the quarterly meetings. At the meeting it appears that PJO Brebes District with a fine Javanese language that is sometimes interspersed with local dialect, very flexible in explaining everything related to SRS. The next role as an intellectual was shown by team members of SRS from Community Health Center of Bumiayu and Kaliwadas while trying to connect the parties involved in this activity. Village midwives have been successfully embraced by enumerators (data collectors) to deliver reports of citizen deaths. They also play a role to show the resident's houses when the officers do the data collection. Approach to citizen by village midwife also support officer when data collection. The role of SRS officers as intellectuals can also be seen when faced with something that is not in accordance with the provisions.

Organic intellectuals are different from traditional intellectuals who tend to isolate themselves in society and form a separate layer floating above society. Organic intellectuals are not separated from society, they realize their position is organically connected to society (Suseno, 2003: 195) [11]. Organic intellectuals express objective tendencies in society and side with the workers. They have the same filling, emotional, and spirit with workers. They must blend with the community in terms of their knowledge, for the smoothness of activities and the achievement coverage of collecting data on mortality. They should describe everything related to the recording of data on mortality, so that it becomes the learning of the other parties.

\section{Discussion}

The recording of data on mortality for all death cases is relatively new activity. Information on death is the starting point of data collection. The problem in many areas is the number of death information of citizens who did not reach the data collection officer. The death information of citizens can reach the officers by involving some parties who are not incorporated in the team. This is need for integration between culture in society with the system applied in the recording of data on mortality. Reporting any incidents of death to the kaur kesra (lebai) or the maid of lebai is actually a social system which is starting point in the activity of recording data on mortality.

Social group belonging to the SRS team have been able to implement their hegemony process by passing through three stages to embrace other parties, so that the activity of recording data on mortality can be run. In the SRS, the three stages of hegemony according to Gramsci can be described as follows: the first phase of SRS team members needs support from other officers so that the activities to be run can be carried out safely, not rejected by the local community. The second stage is the beginning of awareness of SRS team members that there are other parties who share their interests. The division of the role was carried out in accordance with the interests of the officers involved in it. The third stage is that health workers are aware that the smoothness of SRS activities cannot be done only by SRS team members. It is related to information about the deaths of residents from lebai and village midwives. Therefore, support officers from other agencies is needed. These three stages from the results of observations on SRS activities in Bumiayu can be described as follows:

At the beginning of the activity has been held socialization of village midwives in Puskesmas Bumiayu and Kaliwadas. Village midwives were attend the meeting at Bumiayu Health Center and informed about the activities of recording data on mortality. They are also urged to inform the deaths of the residents from lebai to be reported to the trained puskesmas officers. In Kaliwadas Health Center, the socialization of puskesmas officers regarding the recording of data on mortality was conducted during mini workshop. So it is not only village midwives who know about the recording of data on mortality, but all puskesmas officers seem to know the activity. It seems that the village midwives and puskesmas officers then run the appeal. Socialization is an event to explain about activity and purpose of the activity, and get support from other parties.

SRS team members recognize that they must share their interests with others. The SRS team realizes that this activity requires support from other agencies, so that when the first quarter meeting of SRS activities is invited also Camat Bumiayu and all heads of village in Bumiayu.

The death reporting of citizens is very closely related to lebai. Lebai is responsible for it, because of his skill in taking care of the corpse. Therefore, at the second quarter meeting, lebai from each village was invited to attend the meeting. Good approach from the SRS team caused the lebai enthusiastically to respond the SRS activities. The impact is the awareness of the other parties to run activities without compulsion. From this it can be seen that the integration of social systems and bureaucratic system on the work of data collection is stronger.

Hegemony is actually built by a consensus mechanism. As told by one of the lebai in Kalierang Village:

"People here always report events related to birth, death, and divorce to local lebai."

The same thing was also expressed by Secretary of the District (Sekwilcam) Bumiayu. The habit has taken root and becomes a consensus on Bumiayu society, so if there is a case of death then family members quickly report to the local lebai. When Gramsci speaks of consensus, he always deals with psychological spontaneity that includes the acceptance of sociopolitical rules or other rules. Hegemony through consensus arises through active commitment. Therefore, Gramsci said indirectly that consensus as an "active commitment" based on the view that existing high positions are legitimate (Patria and Arief 2003: 123, 126). 
- Mr. Joko and Mrs. Lina who have accepted me to stay there during the research process.

First, the role of Islamic values that support the successful achievement coverage of recording data on mortality in Bumiayu Subdistrict. Islamic values underlie the social system of Bumiayu society regarding the taking care of the corpse. Islam asserts that a person who is dead must be buried soon. Relation to religious teachings cause to the reporting to lebai can be effective, so reporting can be implemented quickly.

Second, the role of SRS officers as organic intellectuals in the work bureaucracy of collecting data on mortality is shown in quarterly meetings, in embracing others, and in the face of something that is inconsistent with the provisions of this activity.

Third, the integration between the social system and the bureaucratic system in the work of collecting data on mortality resulted cooperation between officers who joined and did not belong to the team. It shows hegemony has been running on the cooperation. The established cooperation resulted in good interaction between the two parties as well as increased coverage of recording data on mortality. Fourth, SRS team members have been able to develop ideas about the activities of the Sample Registration System into a ideology. The ideology is socialized to parties outside of team members. After the socialization process, the togetherness between team members and outside parties remains maintained with active commitment. Such conditions caused to potential rejection from other parties who are expected to support can be minimized. There is no rejection caused to the creation of spontaneous obedience. The formation of spontaneous obedience has indicated the equilibrium between the governing and the governed. Such a situation makes it easy for an activity to run.

Fifth, the established hegemony is supported by the collectivity and discipline elements shown by each party involved in the SRS activities.

Sixth, from the findings as the conclusion appears that Gramsci's hegemonic theory can be used to explain the process of running a policy. The observations show that the hegemony of organic intellectuals is needed in embracing others to support a policy.

\section{ACKNOWLEDGMENT}

Special thanks to:

Prof. Dr. Meutia Farida Hatta Swasono and Mr. Irwan Martua Hidayana, $\mathrm{PhD}$ who have guided me throughout the research process to completion.

- $\quad$ SRS Team in Bumiayu Sub-district which has assisted in the data collection process. The Lebai in Bumiayu Subdistrict who have provided a lot of information regarding the management of residents' deaths.

- Head of Bumiayu Sub-district and Heads of Village in Bumiayu Sub-district and their staffs who have supported research in Bumiayu Sub-district.

\section{REFERENCES}

[1] Ministry of Health RI.(2009). Constitution number 36 of 2009. Article 168 paragraph 2. Ministry of Health of the Republic of Indonesia.

[2] Directorate General of Population Administration, Ministry of Home Affairs RI.(2006). Constitution number 23 of 2006 on Population Administration.Director General of Population Administration.

[3] Ministry of Health RI. Joint Regulation of the Minister of Home Affairs and Minister of Health Number 15 Year 2010 with Number 162/Menkes/PB/I/2010 on Reporting of Death and Cause of Death. Ministry of Health RI.

[4] Jennaway, Megan; dkk. (2009). Culturally Sensitive Methods of Eliciting Information on Cause of Death (Verbal Autopsies) in Local Communities: Indonesian Case Studies. School of Population Health, Quensland University dan Badan Penelitian dan Pengembangan Kesehatan, Kementerian Kesehatan.

[5] Cresswell, JW. (2010). Research Design: Qualitative, Quantitative, and Mixed Methods Approaches.Translator: Achmad Fawaid. Desain Penelitian: Pendekatan Kualitatif, Kuantitatif, dan Mixed. Publisher: Pustaka Pelajar.

[6] Gramsci, Antonio. (1987). Selections from the Prison Notebooks. Edited and translated by Quentin Hoare and Geoffrey Nowell Smith. International Publishers, New York.

[7] Patria, Nezar and Arief, Andi. (2003). Antonio Gramsci: Negara dan Hegemoni. Pustaka Pelajar.

[8] Simon, Roger. (2004). Gramci's Political Thought. Gagasan-gagasan Politik Gramsci. Penerjemah Kamdani dan I. Baehaqi. INSIST dan Pustaka Pelajar.

[9] Brown, Trent. (2009). "Gramsci and Hegemony". Link International Journal of Socialist Renewal. http://links.org.au/node/1260. Para. 12, 13, 14.

[10] Geertz, Clifford. (1983). Abangan, Santri, Priyayi dalam Masyarakat Jawa. PT Dunia Pustaka Jaya Cooperation with Yayasan Ilmuilmu Sosial, Jakarta.

[11] Suseno, Frans Magnis. (2003). Dalam Bayangan Lenin, Enam Pemikir Marxisme dari Lenin sampai Tan Malaka. Jakarta: PT Gramedia Pustaka Utama. 